\title{
Acute cytomegalovirus hepatitis in an immunocompetent host
}

\author{
Alexander M Sy, Olabimpe Omobomi, Theodore Lenox, Nora V Bergasa
}

Department of Medicine, Metropolitan Hospital Center, New York and New York Medical College, Valhalla, New York, USA

\section{Correspondence to}

Dr Alexander M Sy,

toshi_sy@yahoo.com

\section{CrossMark}

To cite: Sy AM,

Omobomi O, Lenox T, et al. BMJ Case Rep Published

online: [please include Day

Month Year] doi:10.1136/

bcr-2013-201939

\section{SUMMARY}

A 52-year-old woman presented with a 1-week history of recurrent fevers and joint pains accompanied by abdominal and low back discomfort. She has a history of hypoparathyroidism and is on calcium supplements. Physical examination revealed fever and tachycardia. The rest of the examination was normal. Laboratory tests showed newly increased transaminase activity. Serum bilirubin and prothrombin time were normal. She was admitted for evaluation of acute hepatitis. Serology for hepatitis A, B, C and HIV were negative. Her serum acetaminophen and alcohol were undetected. Abdominal imaging was normal. Cultures were sterile. Additional tests for uncommon viral hepatitis included herpes simplex virus, cytomegalovirus and Epstein-Barr virus. Liver biopsy revealed non-specific inflammation. Subsequently, cytomegalovirus serology showed an IgM positive and negative lgG titre. Cytomegalovirus DNA qualitative PCR was also positive. No antiviral medication was given. She continued to have intermittent daily fever but reported no associated symptoms. She was discharged 9 days after admission in stable condition per her request with the advice to follow-up in the clinic in 1 week. Her serum hepatic profile returned to normal and she reported no more episodes of fever. Repeated titres of cytomegalovirus serology showed seroconversion.

\section{BACKGROUND}

This paper reports acute cytomegalovirus hepatitis. Infection with cytomegalovirus is an unusual cause of acute infectious hepatitis in an immunocompetent adult. Thus, cytomegalovirus hepatitis should be considered in the differential diagnosis in immunocompetent paticipants presenting with non-specific prodromal symptoms and unexplained hepatitis.

\section{CASE PRESENTATION}

A 52-year-old Hispanic woman presented with a 1 -week history of recurrent fevers, non-specific muscle and joint pain accompanied by abdominal and low back discomfort. She has a medical history of hypoparathyroidism and is maintained on calcium supplements. There were no headaches, cough, colds, sore throat, diarrhoea, nausea or vomiting. She denied any history of travelling outside of New York City or the USA. She lived with her husband in a monogamous relationship with no pets at home. She worked as an assistant third-grade teacher and denied sick contacts at work or home. Family and surgical history were unremarkable. She denied smoking, alcohol and drug use. Physical examination revealed a temperature of $102^{\circ} \mathrm{F}$, pulse rate $100 \mathrm{bpm}$ and normal blood pressure. The rest of her physical examination was unremarkable.

\section{INVESTIGATIONS}

Initial laboratory tests included normal complete blood count, chemistry and urinalysis. The serum liver profile revealed newly increased liver-associated enzymes; serum aspartate aminotransferase of $739 \mathrm{U} / \mathrm{L}$ (normal value $15-37 \mathrm{U} / \mathrm{L}$ ), serum alanine aminotransferase $955 \mathrm{U} / \mathrm{L}$ (normal value 30-65 U/L) and serum alkaline phosphatase $170 \mathrm{U} / \mathrm{L}$ (normal value $50-136 \mathrm{U} / \mathrm{L}$ ). Her serum bilirubin and prothrombin time were normal along with chest X-ray. She was admitted to the hospital for evaluation of acute hepatitis. Hepatitis A, B and C serologies were all non-reactive. Serum acetaminophen, alcohol and HIV RNA were undetected. Her hepatobiliary ultrasound, abdominal and chest CT scans were normal. Echocardiogram showed no vegetations.

Following admission, she developed diarrhoea which resolved spontaneously. She continued to have temperature spikes ranging from $102^{\circ} \mathrm{F}$ to $104^{\circ} \mathrm{F}$ despite antipyretics. Blood, urine and stool cultures yielded no pathogens. As she presented with recurrent fevers and joint pains, connective tissue disease, autoimmune and acute metabolic disorders associated with hepatitis were considered. Additional workup to rule out systemic lupus erythematosus, autoimmune hepatitis, immune cholangitis and Wilson's disease included antinuclear antibody, antismooth muscle antibody, liver-kidney microsomal antibody, antimitochondrial antibody and ceruloplasmin level, which were all negative. Markers of inflammation were all elevated such as erythrocyte sedimentation rate was $110 \mathrm{~mm} / \mathrm{hr}$ (normal value 0-30 mm/hr), C reactive protein was $119 \mathrm{mg} / \mathrm{L}$ (normal value $0.2-3.0 \mathrm{mg} / \mathrm{L}$ ), and ferritin was 2248 $\mathrm{ng} / \mathrm{mL}$ (normal value $10-290 \mathrm{ng} / \mathrm{mL}$ ). Additional tests for viral hepatitis due to herpes simplex virus, cytomegalovirus and Epstein-Barr virus were subsequently ordered. She continued to have fever and the activity of her liver enzymes remained high. Thus, in consultation with gastroenterologist, a percutaneous liver biopsy was performed to rule out granulomatous hepatitis. Liver biopsy revealed non-specific inflammation with no granulomata (figure 1). Cytomegalovirus antigen immunohistochemistry was not requested at the time of the biopsy. Subsequently, her cytomegalovirus serology showed positive with an IgM titre of 2.15 (normal range $0-0.89$ ) and $\operatorname{IgG}$ titre of 0.08 (normal range $0-0.9$ ). Cytomegalovirus DNA qualitative PCR is also positive. Herpes simplex and Epstein-Barr virus tests showed negative. 


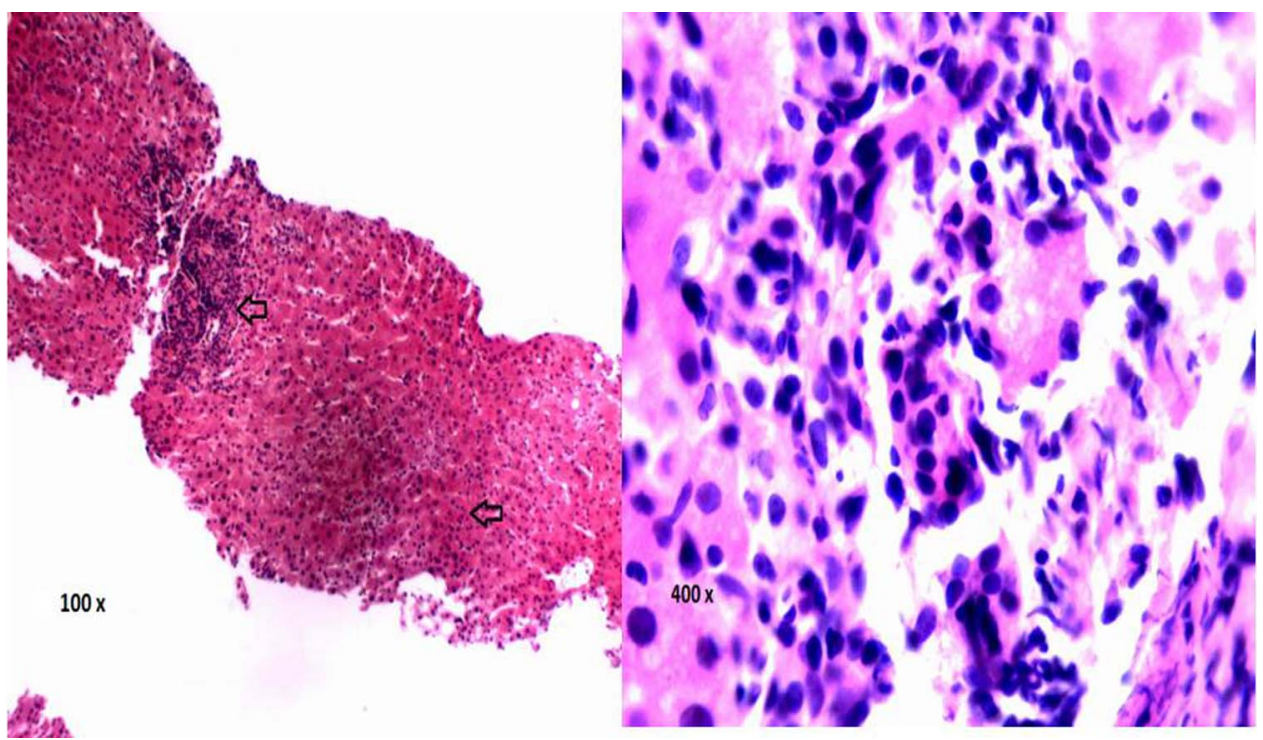

Figure 1 Liver histology on H\&E staining $(\times 100)$ from a percutaneous liver biopsy obtained on day 8 of hospitalisation in a patient with unexplained hepatitis. The arrow shows an area of periportal and lobular inflammation. At $\times 400$ magnification, the area of periportal inflammation can be identified being comprised of mononuclear cells. No cytomegalovirus inclusion bodies were identified.

\section{TREATMENT}

On consultation with an infectious disease specialist, no antiviral was given and patient was managed conservatively with an antipyretic, intravenous hydration and monitoring of liver function and fever pattern.

\section{OUTCOME AND FOLLOW-UP}

Her serum liver-associated enzyme activity slowly trended down. However, she continued to have intermittent fever with Tmax of $102^{\circ} \mathrm{F}$ and no associated symptoms. She was discharged after 9 days of hospitalisation in stable condition at her request with the advice to follow-up in the clinic in 1 week. Her fever resolved and repeat hepatic profile showed serum aspartate aminotransferase of $38 \mathrm{IU} / \mathrm{L}$, serum alanine aminotransferase of $31 \mathrm{IU} / \mathrm{L}$ and serum alkaline phosphatase $73 \mathrm{IU} / \mathrm{L}$. She reported complete resolution of her fever. Repeated titres of cytomegalovirus $\operatorname{IgM}$ and $\operatorname{IgG}$ performed at 1 and 2 weeks after discharge were 5.80 and 2.31 , and 4.94 and 2.53 , respectively, consistent with seroconversion. Three months after hospitalisation, she continued to be doing well and her hepatic enzymes have remained normal.

\section{DISCUSSION}

Cytomegalovirus is a double-stranded viral DNA and is a member of the family Herpesviridae. It is a well-documented infection in an immunocompromised host. However, there are limited reports in immunocompetent individuals as it is typically asymptomatic and often discovered incidentally on routine testing. As in immunocompromised participants, clinical manifestations of cytomegalovirus infection in an immunocompetent adults can range from an infectious mononucleosis-like illness ${ }^{12}$ to a multisystem disease involving the genitourinary, ${ }^{3}$ cardiovascular, $^{4}$ digestive $^{5}$ or the central nervous system. ${ }^{3}{ }^{6}$ In the immunocompetent state, severe disease develops via acquisition of primary cytomegalovirus infection. In contrast, infection can develop in the immunocompromised state through reactivation of latent disease as well as the acquisition of primary cytomegalovirus infection. In a systematic review of immunocompetent patients with cytomegalovirus infection, it was reported that the colon and rectum were the most common primary sites. $^{7}$ Liver involvement is rare and can vary from tender hepatomegaly to fulminant hepatic failure. ${ }^{18}$ Acute cytomegalovirus hepatitis, though unusual, has been reported in immunocompetent adults. ${ }^{1} 3468$ Table 1 provides a summary of PubMed accessible cases of acute cytomegalovirus hepatitis in immunocompetent adults. All cases presented with a nonspecific prodromal state. Thus, cytomegalovirus hepatitis should be included as an important differential diagnosis in an immunocompetent individuals presenting with a non-specific prodromal symptoms and unexplained hepatitis.

Immunocompetent adults are defined as participants without congenital or acquired immunodeficiency states including cancer, transplant recipients, pregnancy and those who are not on immunosuppressive therapy. ${ }^{5}$ The factors that determine the course of cytomegalovirus infection in immunocompetent adults is unclear but host factors probably play a major role, given the limited genetic variability of strains of cytomegalovirus.

Cytomegalovirus has a high seroprevalence (40-100\%) in the general population, ${ }^{5}$ suggesting high rates of subclinical infections. Adult infections are spread through close contact; sources include oropharyngeal secretions, urine, cervical or vaginal secretions, sperm, breast milk and blood. It can also be transmitted iatrogenically through blood, bone marrow and solid organ transplants. $^{2}$ Of note, horizontal spread has been documented in day care settings ${ }^{5}$ and is the probable route of transmission in our patient.

Cytomegalovirus infection can be detected by multiple means. It can be diagnosed by a positive anticytomegalovirus IgM or a fourfold increase in IgG titre, isolation of virus in a culture, via qualitative or quantitative PCR, immunofluorescent assay of cytomegalovirus pp65 antigen in blood or in situ hybridisation and by cytopathology showing the 'owl's eye' intracellular inclusion or positive immunohistochemical staining of the cytomegalovirus antigen. In liver biopsy specimen of immunocompetent patients, the finding of typical cytomegalovirus nuclear inclusions and immunohistochemical staining for cytomegalovirus antigen may be absent in acute cytomegalovirus hepatitis as previously reported. ${ }^{9}$ The pathogenesis behind these 
Table 1 A summary of cases of cytomegalovirus hepatitis in immunocompetent patients

\begin{tabular}{|c|c|c|c|c|c|c|c|c|}
\hline & Case $1^{1}$ & Case $2^{1}$ & Case $3^{1}$ & Case $4^{3}$ & Case $5^{4}$ & Case $6^{6}$ & Case $7^{8}$ & Our patient \\
\hline Age/sex/ethnicity & 22 Male Asian & 26 Male Asian & 32 Male Asian & 16 Male Asian & 32 Male Hispanic & 19 Female Asian & 39 Female Asian & 53 Female Hispanic \\
\hline Presentation & $\begin{array}{l}\text { Jaundice with prior } \\
\text { mononucleosis-like } \\
\text { prodromal symptoms }\end{array}$ & $\begin{array}{l}\text { Jaundice with prior } \\
\text { mononucleosis-like } \\
\text { prodromal symptoms }\end{array}$ & $\begin{array}{l}\text { Jaundice with prior } \\
\text { mononucleosis-like } \\
\text { prodromal symptoms }\end{array}$ & $\begin{array}{l}\text { Comatose, convulsions } \\
\text { and renal failure with } \\
\text { prior fever and altered } \\
\text { mental status }\end{array}$ & $\begin{array}{l}\text { Pleuritic chest pain with } \\
\text { non-specific prodromal } \\
\text { symptoms on } \\
\text { presentation }\end{array}$ & $\begin{array}{l}\text { Fatigue with pain and } \\
\text { numbness of limbs with } \\
\text { prior upper respiratory tract } \\
\text { symptoms }\end{array}$ & $\begin{array}{l}\text { Semicomatose with } \\
\text { persistent fever that was } \\
\text { initially treated for possible } \\
\text { urinary tract infection }\end{array}$ & $\begin{array}{l}\text { Recurrent fever with } \\
\text { prior non-specific } \\
\text { prodromal-like } \\
\text { symptoms }\end{array}$ \\
\hline $\begin{array}{l}\text { Peak ALT IU/L } \\
\text { recorded }\end{array}$ & 1502 & 2937 & 2711 & 1200 & 1178 & 303.8 & 2897 & 955 \\
\hline $\begin{array}{l}\text { Peak AST IU/L } \\
\text { recorded }\end{array}$ & Not documented & Not documented & Not documented & 1003 & 678 & 106.3 & 2349 & 739 \\
\hline $\begin{array}{l}\text { Peak ALP IU/L } \\
\text { recorded }\end{array}$ & Not documented & Not documented & Not documented & 120 & Normal & Not documented & 196 & 170 \\
\hline $\begin{array}{l}\text { Prothrombin time } \\
\text { (seconds) or activity } \\
\text { (\%) recorded }\end{array}$ & $19 \mathrm{~s}$ & $16 \mathrm{~s}$ & $14 \mathrm{~s}$ & $11 \mathrm{~s}$ & $48 \%$ & Not documented & $19.9 \%$ & $10.9 \mathrm{~s}$ \\
\hline $\begin{array}{l}\text { Total bilirubin mg/ } \\
\mathrm{dL} \text { recorded }\end{array}$ & 9.4 & 22.9 & 17.9 & 1.1 & Normal & Not documented & 18.3 & 0.60 \\
\hline Diagnosis & Serum anti-CMV IgM + & Serum anti-CMV IgM + & Serum anti-CMV IgM + & $\begin{array}{l}\text { Serum anti-CMV IgM } \\
+ \text { +and DNA qualitative } \\
\text { PCR+in serum and CSF }\end{array}$ & $\begin{array}{l}\text { Serum anti-CMV IgM } \\
\text { +and+serum pp65 } \\
\text { antigeneamia }\end{array}$ & Serum anti-CMV IgM + & $\begin{array}{l}\text { Serum CMV antigen }+ \\
\text { serum DNA qualitative } P C R \\
+ \text { and }+C M V \text { antigen stain on } \\
\text { liver biopsy }\end{array}$ & $\begin{array}{l}\text { Serum anti-CMV IgM } \\
\text { +and serum DNA } \\
\text { qualitative PCR+ }\end{array}$ \\
\hline Treatment & Conservative no antiviral & Conservative no antiviral & Conservative no antiviral & Acyclovir & Valganciclovir & $\begin{array}{l}\text { Intravenous immunoglobulin } \\
\text { no antiviral }\end{array}$ & Ganciclovir liver transplant & $\begin{array}{l}\text { Conservative no } \\
\text { antiviral }\end{array}$ \\
\hline $\begin{array}{l}\text { Recovery time in } \\
\text { weeks }\end{array}$ & 6 & 9 & 5 & 3 & $4-5$ & 4 & 12 & 2 \\
\hline Complication & No & No & No & No & No & No & No & No \\
\hline
\end{tabular}

ALP, alkaline phosphatase; ALT, alanine transaminase; AST, aspartate aminotransferase; CSF, cerebrospinal fluid; CMV, cytomegalovirus. 
findings is thought to be active destruction of infected cells by the immunocompetent cellular immune system. In our patient, the liver biopsy showed periportal and lobular inflammation of predominantly mononuclear cells, and there was minimal hepatic necrosis with no cytomegalovirus inclusion bodies seen. The diagnosis of acute cytomegalovirus hepatitis was made by positive cytomegalovirus serology and PCR with elevation of the liver-associated enzymes.

Guidelines for the treatment of cytomegalovirus hepatitis in immunocompetent adults have not been published. ${ }^{7}$ Available literature suggests that antiviral therapy is reserved for severe cases and life-threatening conditions. ${ }^{3} 478$ Treatment should proceed in an individualised manner, weighing the risks of medication adverse effects versus the benefits of improving disease outcome.

\section{Learning points}

- Cytomegalovirus hepatitis is an important differential diagnosis in immunocompetent adults presenting with a non-specific prodromal symptoms and unexplained hepatitis.

- Fever and hepatitis in immunocompetent adults are usually attributed to the common hepatotrophic viruses, namely hepatitis A, B and C; however, viral hepatitides such as cytomegalovirus can also cause severe hepatitis.

- Diagnosis of cytomegalovirus infection can be performed through multiple means. However, the typical findings of cytomegalovirus nuclear inclusions and immunohistochemical staining for cytomegalovirus antigen in the liver biopsy specimens of immunocompetent patients may be absent, possibly due to active destruction of infected cells by the immunocompetent cellular immune system.

- Antiviral treatment for cytomegalovirus hepatitis in immunocompetent adults is reserved for severe cases and in life-threatening conditions. Treatment should be individualised, weighing the risks of medication adverse effects versus the benefits of improving disease outcome as some patients respond to conservative therapy.
Contributors Equal contributions were provided by all the authors. AMS, OO, NVB and TL took care of the patient, wrote the manuscript, was involved in the review of literature, retrieve pathology slide and edited the manuscript.

Competing interests None.

Patient consent Obtained.

Provenance and peer review Not commissioned; externally peer reviewed.

\section{REFERENCES}

1 Mahtab MA, Rahman S, Khan M. Acute cytomegalovirus hepatitis in immunocompetent host. Kathmandu University Med J 2009;7:79-81.

2 Vancikova Z, Dvorak P. Cytomegalovirus Infection in immunocompetent and immunocompromised Individuals—a review. Curr Drug Targets Immune Endocr Metabol Disord 2001;1:179-87.

3 Khattab MA, Eslam M, Abd-elfattah ME. Encephalitis, acute renal failure, and acute hepatitis triggered by a viral infection in an immunocompetent young adult: a case report. J Med Case Rep 2009;3:9289.

4 Fernandez-Ruiz M, Munoz-Codoceo C, Lopez-Medrano F, et al. Cytomegalovirus myopericarditis and hepatitis in an immunocompetent adult: successful treatment with oral valganciclovir. Inter Med 2008;47:1963-6.

5 Galiatsatos P, Shrier I, Lamoureux E, et al. Meta-analysis of outcome of cytomegalovirus colitis in immunocompetent hosts. Dig Dis Sci 2005;50:609-16

6 Ma Y, Feng J, Qi Y, et al. An immunocompetent adult patient with hepatitis and guillain-barre syndrome after cytomegalovirus infection. Virol J/ 2011;8:95.

7 Rafailidis PI, Mourtzoukou EG, Varbobitis IC, et al. Severe cytomegalovirus infection in apparently immunocompetent patients: a systematic review. Virol Jl 2008:5:47.

8 Yu YD, Park GC, Park PJ, et al. Cytomegalovirus infection-associated fulminant hepatitis in an immunocompetent adult requiring emergency living-donor liver transplanatation: a report of a case. Surg Today 2013:43:42-8.

9 Snover DC, Horwitz C. Liver disease in cytomegalovirus mononucleosis: a light microscopical and immunoperoxidase study of six cases. Hepatology 1984;4:408-12.

Copyright 2013 BMJ Publishing Group. All rights reserved. For permission to reuse any of this content visit http://group.bmj.com/group/rights-licensing/permissions.

BMJ Case Report Fellows may re-use this article for personal use and teaching without any further permission.

Become a Fellow of BMJ Case Reports today and you can:

- Submit as many cases as you like

- Enjoy fast sympathetic peer review and rapid publication of accepted articles

- Access all the published articles

- Re-use any of the published material for personal use and teaching without further permission

For information on Institutional Fellowships contact consortiasales@bmjgroup.com

Visit casereports.bmj.com for more articles like this and to become a Fellow 